\title{
ЧЕТВЕРТОЕ ЗАСЕДАНИЕ СЕМИНАРА \\ “СОЦИАЛЬНАЯ ФИЛОСОФИЯ И РАЗВИТИЕ ГРАЖДАНСКОГО ОБЩЕСТВАВ РОССИИ»: «ГРАЖДАНСКОЕ ОБЩЕСТВО: ПРОБЛЕМЫ СТАНОВЛЕНИЯ ЕГО В РОССИИ»
}

\author{
Ч. К. Ламажаа \\ (Московский гуманитарный университет)
}

Аннотация: В статье представлен обзор работы четвертого заседания семинара «Социальная философия и развитие гражданского общества в России», которое состоялось в Институте философии РАН 11 февраля 2016 г. Основной доклад заседания на тему «Гражданское общество: проблемы становления в России» делал д-р филос. н., проф. И. К. Пантин.

Ключевые слова: Институт философии РАН; гражданское общество; научный семинар; обзор

\section{$4^{\text {TH }}$ SESSION OF "SOCIAL PHILOSOPHY AND THE DEVELOPMENT OF CIVIL SOCIETY IN RUSSIA" SEMINAR: "CIVIL SOCIETY AND THE ISSUES OF ITS RISE IN RUSSIA"}

\author{
N. V. Zakharov \\ (Moscow University for the Humanities)
}

Abstract: This is a review of the 4th session of the seminar "Social philosophy and the development of civil society in Russia", which took place on February 11, 2006, at the Institute of Philosophy, Russian Academy of Sciences. Doctor of Philosophy, Professor I.K. Pantin presented a paper titled "Civil society and the issues of its rise in Russia".

Keywords: Institute of Philosophy, Russian Academy of Sciences; civil society; research seminar; review

11 февраля 2016 г. в Институте философии РАН состоялось очередное заседание семинара «Социальная философия и развитие гражданского общества в России» (руководители семинара - д-р филос. н., проф. В.Г.Федотова и д-р филос.н. В. А. Колпаков). Семинар проводится в рамках одноименного научного направления ИФРАН, руководителем которого является В. Г. Федотова. Она представила докладчика на четвертом заседании. Тема была сформулирована как «Гражданское общество: проблемы 
становления его в России». Докладчиком выступил д-р филос.н., проф., научный советник журнала «Политические исследования» И.К.Пантин.

И. К. Пантин построил свое выступления, последовательно отвечая на ряд вопросов: 1) Когда и как появляется концепция гражданского общества; 2) Определение гражданского общества. Гражданское и политическое; 3)Гражданское общество как средство демократической легитимности; 4) Проблема гражданского общества в России; 5) Особенности российского государства и «государственническая» психология населения; 6) Как можно вести диалог с российской бюрократией; 7) Проблема центра и регионов в становлении гражданского общества вРоссии.

По словам И. К. Пантина, многие характеристики современного общества представляют собой проблемы, требующие незамедлительного разрешения. Оглядываясь с прошлое, докладчик сказал, что «в России никогда не было гражданского общества, которое бы существовало вместе с государством». «Демократические ценности и понятия в современной России пройдут еще долгий путь». При этом собственно проблема гражданского общества в нашей стране до сих пор обсуждается, прежде всего как теоретическая. А концепция гражданского общества, по словам Игоря Константиновича, не либеральная и не социальная идея, и в целом он сам не стал бы говорить о гражданском обществе как концепции, это скорее концепт. Для него идея гражданского общества - это попытка преодолеть оппозицию государства и общества. И в каждой стране эта попытка должна формулироваться как своя концепция.

В основе понимания гражданского общества, по мнению докладчика, находится способность самоорганизации общества по восстановлению социальных рамок для всех ограничителей прав и свобод. В соответствии с этим пониманием к гражданскому обществу сложно отнести какие-либо организации, политические партии, точно также и простые совокупности граждан не организуют гражданского общества. «Гражданское общество начинается тогда, - подчеркнул И. К. Пантин, - когда граждане обнаруживают возможность осуществления общественных действий во благо общества». Гражданское общество тем самым является не постоянным структурным элементом современного общества, а исчезающей, временной характеристикой. Здесь он привел образ Б. Капустина, который назвал гражданское общество улыбкой Чеширского кота.

В России, по определению И. К. Пантина, много общественных организаций, много активности «снизу», что можно назвать ростками гражданского общества. Но у этих организаций нет диалога с властью. Помимо этого причинами трудностей в становлении гражданского общества в России докладчик также назвал иной, чем в Европе, исторический опыт развития, многонациональность общества, влияние территориального 
фактора (огромной территории).

Деятельность нынешнего Президента России В. В. Путина И. К. Пантин в целом оценил положительно в деле демократизации общества. Однако гражданское общество здесь только возникает и это остается фактом, сложной проблемой и ее невозможно решить мерами «сверху». «В последнее время власть стала претендовать на то, что только он способна создать гражданское общество», - сказал докладчик, напоминая собравшимся об инициированном руководством страны «Всероссийском Народном фронте». Но, по его словам, гражданское общество в принципе не может быть создано властью и при помощи власти. Власть может только обеспечить условия для развития гражданского общества.

Слушатели восприняли доклад с большим интересом и задали множество самых разных вопросов докладчику. Особый интерес составили вопросы об отнесении (или не отнесении) партий к гражданскому обществу, о том как квалифицировать выступления граждан по разным вопросам, о вкладе ученых в становление гражданского общества. Собравшиеся пришли к мнению о том, что гражданское общество обусловлено наличием социальных проблем и в случае их отсутствия гражданское общество становится ненужным и в этом есть парадокс.

На странице семинара на сайте Института философии РАН размещена аудиозапись данного заседания: http://iph.ras.ru/uplfile/socph/pantinik---civil-so.mp3

В заседании приняла участие д-р филос. н., заместитель директора Института фундаментальных и прикладных исследований Московского гуманитарного университета Ч. К. Ламажаа.

Дата поступления: 24.02.2016 г.

Ламажаа Чимиза Кудер-ооловна - доктор философских наук, заместитель директора Института фундаментальных и прикладных исследований Московского гуманитарного университета. Адрес: 111395, Россия, г. Москва, ул. Юности, д. 5, корп. 6.Тел.: +7 (499) 374-59-30. Эл. адрес: lamajaa@mail.ru

Lamazhaa Chimiza Kuder-oolovna, Doctor of Philosophy, Deputy Director, Institute of Fundamental and Applied Studies, Moscow University for the Humanities; Full Member, International Academy of Science (Innsbruck, Austria). Postal address: 5 Yunosti St., 111395Moscow, Russian Federation. Tel.: +7 (499) 374-75-95. E-mail: lamajaa@mail.ru 